Годишњак Филозофског факултета у Новом Саду, Кьига ХХХІХ-1 (2014)

Annual Review of the Faculty of Philosophy, Novi Sad, Volume XXXIX-1 (2014)

Snežana Božanić

Filozofski fakultet Univerziteta u Novom Sadu

UDK 271.22(497.11)“1954/1965“:

929 Đorđević B.Č.

Originalan naučni rad

\title{
PROŠLOST BAČKOG BRESTOVCA U DISKURSU CRKVENE DELATNOSTI BORIVOJA Č. ĐORĐEVIĆA (1954-1965) ${ }^{1}$
}

U radu se prati delatnost bačko-brestovačkog pravoslavnog sveštenika Borivoja Č. Đorđevića. Ovaj veliki čovek ostavio je dubok i neizbrisiv trag na duhovnoj i istorijskoj pozornici Bačkog Brestovca i okoline. Hronološki, rad obuhvata period od 1954. do 1965. godine. Od 1937. paroh Đorđević se nalazio na čelu „Društva za podizanje spomen-crkve sa kosturnicom u Lazarevcu“. U kosturnici crkve Svetog Dimitrija (Lazarevac) sahranjeni su posmrtni ostaci stradalih vojnika u Kolubarskoj bici 1914. godine. Krajem 1964. godine došao je u Bački Brestovac. Pola godine kasnije, zahvaljujući njegovom zalaganju izvršeni su značajni radovi na podizanju tornja i opravci sv. Hrama. Neumorno je organizovao Svetosavske svečanosti, držao versku nastavu i propovedi, širio duhovnost i toleranciju. Sa posebnom pažnjom se odnosio prema hramovnoj slavi. Uzimao je aktivnog učešča u prikupljanju pomoći za postradale od poplava, zemljotresa i drugih elementarnih nepogoda, na prostoru nekadašnje Jugoslavije. Uredno, marljivo i korektno je vodio „Letopis parohije“. Održavao je dobre odnose sa predstavnicima Katoličke crkve. U više navrata, Episkop Bački Nikanor je posećivao bačkobrestovačku parohiju, o čemu postoje značajna pisana svedočanstva. Za marljiv i vredan rad odlikovan je najpre pravom nošenja crvenog pojasa, a kasnije je postao protonamesnik. Istorija sv. Hrama predstavlja istoriju parohije i njenih ljudi, koja je uklopljena u šira društvena zbivanja, narečenog perioda.

Ključne reči: sveštenik Borivoje Č. Đorđević, Hram sv. Apostola Petra i Pavla u Bačkom Brestovcu, crkvena istorija

Bački Brestovac se prvi put dokumentovano pominje u prvoj polovini XVI veka, u urbarijalnom popisu iz 1543. godine, pod nazivom „Nagy-Bresztovácz (major)“. Davao je godišnji harač u iznosu od 16 novčića (Borovszky, 1909, 154). Bio je to period kada je Bačka, odnosno ovaj deo tadašnje južne Ugarske dopseo pod vlast Osmanskog carstva. Prema Defteru Segedinskog sandžaka (1553. dec. 6. - 1554. nov. 24) „Beresztács“ je imao ukupno 10 kuća, od kojih su tri plaćale harač, a sedam nije (Popović, 1925, 120-125). „Bresztovo“ je oko 1570. imalo 5 kuća koje su plaćale harač, a 1590. godine osam. Tokom Velikog Bečkog rata Turci su bili proterani iz Bačke, a ovaj deo Podunavlja je u sklopu Habsburške monarhije

sbozanic5@gmail.com Rad je fazni rezultat projekta Ministarstva za prosvetu i nauku: Vojvođanski prostor u evropskoj istoriji br. 147002. 
imao važnu militarnu ulogu. Naime, Sombor je 1702. dobio status vojnog šanca (Fossatum Militare), na novostvorenoj Potiskoj vojnoj granici. Brestovac „selo i šanac" se našao pod Segedinskom vojnom komandom, i pripadao je Somborkoj miliciji. U drugoj polovini 1745. godine, rasformirani su granični šančevi Subotica, Sombor, Brestovac i Palanka.

Početkom XVIII veka Brestovac je bio isključivo naseljen stanovništvom pravoslavne veroispovesti. Zahvaljujući Srbima graničarima, podignuta je crkva, skromnog izgleda. Najverovatnije, na mestu današnjeg hrama, postojala je neka vrsta kapele još od prvih dana postojanja naselja. Hram posvećen Svetim apostolima Petru i Pavlu podignut je 1743. a osvećen 6. avgusta 1744. godine (Andraši, 2001, 35). Crkva je više puta u svojoj istoriji dograđivana i zidana, da bi današnji izgled poprimila u XIX veku. Na ovom mestu, valja napomenuti da je jedan od najpoznatijih Brstovčana XIX veka bio Atanasije Nikolić (1803-1882). Stekao je široko obrazovanje tokom školovanja u Sremskim Karlovcima, Đeru, Beču i Pešti gde je dobio zvanje inženjera (geodezija). Prešavši na službu u Kneževinu Srbiju, 1838. godine je postao profesor i kasnije rektor na novoosnovanom Liceju u Kragujevcu. Bio je redovni član Društva srpske slovesnosti (1848), a zatim i počasni član Srpskog učenog društva (1864). Upravo je na Nikolićev predlog od 1840. godine, „Savindan“ ustanovljen u kneževini Srbiji kao školska slava (Srećković, 1884, 115-118).

U doba vladavine carice Marije Terezije (1740-1780) dolazi do naseljavanja Nemaca, i u daleko manjem broju Francuza, u Brestovac. Tokom XX veka, u granicama Kraljevine SHS/Jugolsavije, i zatim socijalističke Jugolsavije, srpsko stanovništvo u dve značajne migracije naseljava ovo mesto. U aprilu 1924. godine, naseljene su 44 srpske porodice iz okoline Budimpešte (Pomaz, Čib, Čobanac), u selo. Bili su to tzv. „Srbi Optanti“, po kojima se jedan kraj sela i danas tako zove (Gaćeša, 1968, 195). Nakon završetka Drugog svetskog rata, Nemci napuštaju mesto, da bi tokom jeseni 1945. godine u Bački Brestovac bilo doseljeno 950 srpskih porodica sa 5270 članova. Kolonisti su bili iz Brinja, Korenice, Otočca, Gospića, Bihaća i drugih krajeva.

Socijalistički društveni poredak i proces takozvane ,industrijalizacije“ Odžačke opštine kojoj je Brestovac pripadao dao je novi pravac razvoja i ovog mesta. Upravo u povoju socijalističkih decenija u Brestovcu je svoju službu započeo jedan sveštenik Srpske pravoslavne crkve (dalje: SPC), Borivoje Č. Đorđević, čija će crkvena i široka društvena delatnost obeležiti jedan deo istorije ovog mesta. Cilj ovog rada će biti da se uprvo na osnovu do danas ne istražene istorijske građe, sagleda prošlost Bačkog Brestovca kroz diskurs dela Borivoja Đorđevića.

Borivoje Č. Đorđević je 28. avgusta 1954. bio imenovan za privremenog bačko-brestovačkog paroha. Do tada, bio je paroh lazarevački i arhijerejski namesnik kolubarsko-posavski (Eparhija šumadijska). Rođen je 9. septembra 1909. u Jeloviku, od oca Čedomira i majke Ljubice (rođ. Stojanović). Skolovao se u rodnom selu, Aranđelovcu, a Bogosloviju je završio u Sremskim Karlovcima 1931. godine. Rukopoložen je na praznik Sv. Tri jerarha 1933. godine u čin đakona, i postavljen je za đakona crkve u Topoli (Šumadija). Vrlo brzo, 15. jula 1934. godine postao je 
privremeni paroh u Lazarevcu. Od 1937. nalazio se na čelu „Društva za podizanje spomen-crkve sa kosturnicom u Lazarevcu“. Crkva je podignuta na osnovu projekta arhitekte Ivana Rika 1938-1941. U kosturnici crkve Svetog Dimitrija (Lazarevac) sahranjeni su posmrtni ostaci stradalih vojnika u Kolubarskoj bici 1914. godine. Crkva je podignuta u srpsko-vizantijskom stilu. „Njegovim ličnim zalaganjem" podignuta je u rečenom mestu Spomen kosturnica (Letopis parohije BB, 1955-1967, 31). Za svoje zasluge bio je od strane viših crkvenih vlasti 1946. godine odlikovan pravom nošenja crvenog pojasa, da bi 1952. godine postao arhijerejski namesnik kolubarsko-posavski.

Sredinom oktobra 1954. bio je uveden u dužnost bačko-brestovačkog paroha. Svečanu liturgiju su služili arhijerejski namesnik somborski, prezviter Dragutin Simić, jerej Stevan Opančarev, paroh staparski i paroh Đorđević. Na sv. Arhangela Mihaila (21. novembar 1954), novi paroh je uputio apel vernicima da svojim prilozima pomognu obnavljanje crkve, naredne godine. Tim povodom, osnovana je knjiga „Spomenica“, u koju su upisivani prilozi. Tokom 1954. godine, održano je sedamnaest sednica Privremenog poverenstva Crkvene opštine (dalje: PPCO) u Bačkom Brestovcu, na kojima je doneto ukupno 58 odluka. Božić 1955. godine je proslavljen uz prisustvo velikog broja vernika. Još veći broj parohijana prisustvovao je Svetosavskoj proslavi, čiji domaćin je bio Miladin Stojkov. U parohiji „kult mrtvih je bio slabo razvijen“. Na Zadušnicama, marta 1955. sv. hram je bio slabo posećen, pri čemu je bilo „više prisutnih Ličanka od meštana“ (Letopis parohije BB, 1955-1967, 33). Pod „meštanima“ se podrazumevaju Srbi koji su živeli u Bački Brestovac pre 1945. godine.

$\mathrm{Na}$ dan sahrane episkopa bačkog Irineja (Blagovesti, 7. april) u Bačkom Brestovcu je održana komemorativna sednica, na kojoj je paroh Đorđević govorio o životu i radu upokojenog episkopa (Sava, episkop šumadijski, 1996, 201). Odlukom od 16. maja 1955. godine, potvrđeno je novo PPCO Bački Brestovac od 11 članova (E. U. O. br. 164). To su bili: paroh Borivoje Č. Đorđević, Svetozar Popović, Žarko Katanić, Slavko Berić, Đura Gojković, Petar Jezdimirović, Milenko Popović, Vasa Lazić, Nedeljko Zarić, Stevan Drakulić i Nikola Cvetičanin. Već 29. maja izvršeno je njegovo konstituisanje i položene su zakletve. Za predsenika je izabran Svetozar Popović, potpredsednika Đura Gojković, blagajnika Milenko Popović, a za sekretara paroh Đorđević. Tutori su postalii: Ilija Beljanski i Sava Zarić (Zapisnik sednica COU 21.1.1940-25.12.1955, Prva sednica održana 29. 5. 1955). Agilni paroh Đorđević je odmah predložio da svi članovi Uprave apeluju kod vernika radi prikupljana priloga, koji su bili neophodni za izgradnju tornja i opravku hrama. Predlog je jednoglasno prihvaćen. Izabran je Građevinski odbor od četiri člana, koji će dežurati na gradilištu i voditi računa da se radovi izvode po planu. U Odbor su ušli: Stevan Drakulić, Mileta Popović, Nedeljko Zarić i Ilija Beljanski. Pitanje krečenja crkve, opravke oluka i sata na tornju, našlo se već na drugoj redovnoj sednici Privremenog poverenstva, koja je održana nedelju dana kasnije (Zapisnik sednica $\mathrm{COU}^{2}$ 21.1.1940-25.12.1955, Druga sednica održana 7. 6. 1955).

Crkveno opštinska uprava (dalje: COU). 
Crkvena opština (dalje: CO) je tokom 1954. i 1955. dala Matici srpskoj u Novom Sadu 18 starih ikona kao pozajmicu. Na trećoj sednici Privremenog poverenstva (12. 6. 1955.) doneta je odluka da se pomenute ikone prodaju Matici (za 316000 dinara), a novac upotrebi za opravku crkve. Jedanaest starih ikona su tom prilikom dali na restaururanje i čuvanje ovoj kulturnoj instituciji u Noovm Sadu (Lazić, 1998, 406). Tim povodom je, nakon dva dana, blagajnik Milenko Popović išao za Novi Sad.

Radovi na podizanju tornja i opravci sv. hrama otpočeli su krajem maja 1955. godine a završeni 7. jula, što je konstatovano na petoj sednici Privremenog poverenstva (24. 7. 1955). Prethodno je rešeno da toranj ,treba ofarbati u rezeda boji - grašak boja“ a „crkvu okrečiti u jednostavnijoj sasvim otvorenoj - žutoj boji“ (Zapisnik sednica COU 21.1.1940-25.12.1955, Četvrta sednica održana 26. 6. 1955). Povodom završetka radova izdata je „Povelja“ (7. jul 1955) koju je izradio Svetolik Karadžić iz Beograda:

„U ime Oca i Sina i Svetog Duha Amin! Leta Gospodnjeg, devet stotina pedeset i druge, 16. juna u noćnom času, sručio se uragan, nezapamćena bura na naš Bački Brestovac, tako da je srušio zvonik - toranj hrama sv. Apostola Petra i Pavla. Opravka i podizanje iznova početa je u desetom letu F.N.R.J. pod vođstvom prvog predsednika naše Republike Druga Tita Maršala Jugoslavije uz blagonaklonost narodnih vlasti i sadejstvo Projek. Zavoda u Novom Sadu. Projekat izradio Oto Dreer. Blagoslovom Nj. Pr. Episkopa Bačkog gospodina Nikanora i pregnućem jereja Bor. Č. Đorđevića (došavšeg na parohiju 17-X-1954) ubrzan je rad na tom poslu 17-V-1955. i srećno završen 7-VII-1955. Na dan Ustanka - Ivanjdan. Poverenstvo Cr. Opštine: predsednik Svetozar Popović, potpredsednik Đura Gojković, blagajnik Milenko Popović. Članovi: Nikola Cvetičanin, Žarko Katanić, Stevan Drakulić, Slavko Despotov, Slavko Berić, Vasa Lazić, Petar Jezdimirović i Nedeljko Zarić. Tutori: Sava Zarić i Ilija Beljanski. Nadzornik, inžinjer arhitekta Lazar Racković iz Odžaka. Građevinske i tesarske radove izvodio je Borislav Mitić, građevinar iz Srpskog Miletića. Limarske radove izveli su: Stevan Doboš i Miloš Vlajinić, limari iz Odžaka. Sat na tornju opravio je Tadija Vranić iz Bača. Povelju izradio Karadžić Svetolik iz Beograda“ (Letopis parohije BB, 1955-1967, 36).

Ukupna vrednost radova iznosila je 610986 dinara. Na posebnoj sednici Privremenog poverenstva, predsednik Svetozar Popović je pohvalio rad sveštenika i sekretara, jereja Borivoja Č. Đorđevića „koji se požrtvovano zalagao od svog dolaska za našu parohiju i kome pripada velika zasluga za postignuti uspeh oko izgradnje tornja i opravke sv. Hrama“" (Zapisnik sednica COU 21.1.1940-25.12.1955, Peta sednica održana 24. 7.1955).

Početkom jula 1955. godine, episkop sremski Nikanor, izabran je za episkopa Eparhije bačke (Sava, episkop šumadijski, 1996, 358-359). Predsenik Poverenstva Svetozar Popović, sekretar i paroh Đorđević, lično su čestitali novom episkopu izbor i ustoličenje. Pozvali su episkopa da za crkvenu slavu dođe u Bački Brestovac, kada je bilo predviđeno osvećenje obnovljenog hrama Svetih apostola Petra i Pavla. Episkop Nikanor, međutim, zbog obaveza nije bio u mogućnosti da poseti 
mesto tom prilikom, ali je „obećao da će doći u septembru, radi osvećenja sv. hrama“" (Letopis parohije BB, 1955-1967, 35). Liturgiju za crkvenu slavu (12. juli 1955) pored bačko-brestovačkog paroha služili su: arhijerejski namesnik Dragutin Simić, jerej Stevan Opančar, paroh staparski, jeromonah Mitrofan, paroh lalićki. Na samom kraju izvršen je ophod i pomen na severnim vratima ktitorima, osnovateljima i priložnicima sv. hrama. Domaćin slave bio je Đurica Zarić, a oko 15 h izvršeno je svečano vodoosvećenje, osvećenje koljiva i rezanje slavskog kolača.

Pošto su poslovi na izgradnji tornja, kao i opravka crkve, uspešno okončani, trebalo je radove osveštati po kanonima i pravilima SPC. Na šestoj sednici Privremenog poverenstva (21. avgust 1955) doneta je odluka da se na osvećenje pozove episkop bački g. Nikanor. Predviđeno je da se osvećenje obavi 18. septembra (nedelja pred Malu Gospojinu). Sve je zahtevalo opsežne pripreme. Taj dan, „ostaće kao jedan vrlo važan istorijski datum u razvitku brestovačkog sv. hrama“ (Zapisnik sednica COU 21.1.1940-25.12.1955, Šesta sednica održana 21. 8. 1955). Episkop je po prvi put dolazio u mesto i parohiju. Osvećenje tornja i obnovljenog hrama izvršeno je (18. septembra) na crkveni praznik svetih proroka Zaharije i pravedne Jelisavete (Episkop Nikolaj, 2001, 632-633). Episkop je svojim dolaskom uvećao ovu svečanost. U Bački Brestovac, stigao je ranim jutarnjim vozom u $5 \mathrm{~h}$ i $45 \mathrm{~min}$. Tim povodom, odmah su se oglasila zvona. Njegovo preosveštenstvo na putu od Železničke stanice do sv. hrama pratili su svečano okićeni konjanici. Od ranih jutarnjih sati, narod je hitao ka pravoslavnoj crkvi da uzme učešća u proslavi i pozdravi arhijereja. Na kapiji se nalazio slavoluk sa natpisom: „Dobro nam došao“. Devojke i mladići su bacali cveće.

Na samom ulasku u crkvu, episkopu je prišao arhijerejski namesnik Dragutin Simić, poželeo mu dobrodošlicu i predao krst. Pozdravljen je recitacijom od strane učenice Rajke Radić, a Verica Popović, Jelka Aperlić i Seka Zarić su mu uručile cveće. Nakon toga usledio je pozdravni govor predsednika CO Svetozara Popovića. Po dugoj tradiciji, „tri blagočestive žene“ Đurđina Beljanski, Olga Rusov i Gina Simić uvele su g. Nikanora „u sv. hram po platnu“ (Letopis parohije BB, 19551967, 38). Nakon obreda, episkop je u parohijskom domu izvršio pregled matičnih knjiga, delovodnika, Letopisa, rad Crkvene opštine i paroha, a sa naročitom pažnjom je pregledao dokumentaciju koja se odnosila na popravku sv. hrama.

Tom prigodom nastao je zapis, koji donosimo u celini (Letopis parohije BB, 1955-1967, 39):

„Dana 18/5. septembra 1955. godine, u nedelju o sv. Zahariji i Jelisaveti posetili smo Bački Brestovac i obavili malo osvećenje Hrama, koji je trudom i vrednim marom izvršila SPCO u Bačkom Brestovcu. Jereju Borivoju Č. Đorđeviću pripada velika zasluga na ovom bogougodnom delu. Bog neka blagoslovi njega i njegovu porodicu i njegovu bogoljubivu pastvu.

Episkop bački Nikanor"

Nakon osvećenja crkve i novopodignutog tornja, otpočela je svečana liturgija. Somborski muški hor pod upravom Bogdana Laloševića uzeo je učešća u svečanosti. Episkop je održao propoved u kojoj je, između ostalog, pozvao ,naseljenike i 
meštane da žive u slozi, hrišćanskoj ljubavi i da poput svojih predaka čuvaju svoju veru pradedovsku i slavnu tradiciju SPC“ (Letopis parohije BB, 1955-1967, 39). To je bio ,jedan od najsvečanijih dana u istoriji brestovačkog sv. hrama“, zabeležio je u letopisu, njegov autor Borivoj Đorđević.

Mnoge brestovačke kuće, početkom 1956. godine ležale su pod vodom. Znatan broj je pretrpeo oštećenja, a neke su i pale. Sve to se neminovno odrazilo na materijalne prilike parohijana, koje su i inače bile skromne. Borivoje Đorđević, je 14. januara 1956. godine održao propoved „Sreća po učenju Hrišćanske crkve“. Potom je CO podneo izveštaj za prethodnu godinu. Proslava Sv. Save je obavljena dostojanstveno, a kum slave je bio Sava Popović. Paroh u „Letopisu“ detaljno navodi Program proslave: naslove pesama, njihove autore i imena dece koja su ih izvela (Letopis parohije BB, 1955-1967, 41-43). Za hramovnu slavu 1956. godine, liturgiju su služili protojerej Ivan Popović, paroh staparski, i brestovački sveštenik. Hor učenika je pevao pod upravom bogoslova Milana Delića, a kum slave je bio blagajnik crkvene opštine Milenko Popović. Početkom 1957. godine, paroh Borivoje C. Đorđević je za svoj rad i zasluge bio od strane episkopa odlikovan naslovom „protonamesnika“ (E. Br. 8 iz 1957). Za praznik Sv. Save, paroh je održao predavanje o „Svetosavskim idealima“. Kum slave bio je Božo Radić. Bogat program, sa odabranim recitacijama i uz učešće hora, se sastojao od 54 tačke. Na Zadušnice (23. 2. 1957) crkva je bila prepuna. Nakon propovedi „O kultu mrtvih“, paroh je otišao na mesno groblje i prekadio grobove bivših sveštenika.

Uskoro je protonamesnik Đorđević pokrenuo akciju za kupovinu letnje odežde. Ukupno, 61 priložnik uzeo je učešća u ovoj aktivnosti. Prikupljena je suma od 15791 dinar, koliko je koštala odežda, osveštana prvog dana Uskrsa. Arhijerejski namesnik, protojerej Dragutin T. Simić je 14. 5. 1957. pregledao Letopis CO i parohije koji je prema njegovim rečima „marljivo vođen“. To je potvrdio potpisom i pečatom. Sredinom maja 1957. namešteni su i osveštani tutorski sto i dva stola u ženskoj crkvi. Radove je obavio T. Staničkov iz Stapara. Krajem jula, obnovljeni su crkveni barjaci. Neophodan materijal je kupljen u Svešteničkoj zadruzi, a dobrovoljno su ih izradile: Sofija i Vera Stanišić, Julka Brajić i Soka Popović.

Crkvena slava 1957. proslavljena je u skladu sa dopisom episkopa bačkog g. Nikanora o hramovnim slavama (E. Br. 115) na sledeći način:

a) „Strogo crkveni deo slave“

b) „Narodno - crkveni deo slave“

c) „Čisto narodni deo slave“

Na drugoj sednici Privremenog poverenstva detaljno se raspravljalo o proslavi hramovne slave. „Strogo crkveni deo slave“ i njegovu organizaciju u potpunosti je na sebe preuzeo mesni paroh (Zapisnik UO SPCO 19.2.1956-3.1.1972, Druga redovna sednica PP 30. 5. 1957).

Po prvi put, uvedeno je praznično bdenije uoči slave. Na sam praznik, liturgiju sa početkom u 9 h služili su mesni paroh, Uroš Jovankin, paroh somborski i Stevan Opančarev, paroh staparski. Učestvovao je ženski hor iz Sombora, pod upravom g. Đure Simića. Propoved, „Vaspitanje dece kao najsvetiji zadatak rodi- 
telja“, održao je jerej Uroš Jovankin. Večernje je počelo u 14 h i 30 min, uz služenje pomenuta tri sveštenika. Paroh staparski je govorio na temu „Značaj hramovnih slava“. Kum slave bio je Milan Lazić, tutor iz Bačkog Brestovca. Jova Popović je „rado“ prihvatio kumstvo za narednu godinu. Nakon toga, deca koja pohađaju versku nastavu, izvela su duhovne pesme i religiozne recitacije (Letopis parohije BB, 1955-1967, 53-54). Sve se odvijalo pod rukovodstvom Milana Delića, koji je završio tada treću godinu bogoslovije u Rakovici. Narednog dana održan je parastos svim ktitorima i dobrotvorima crkve sv. Apostola Petra i Pavla. Krajem jula 1957. godine, paroh Đorđević i Žarko Katanić, član Crkvenog odbora posetili su Dalj, sa ciljem upoznavanja tamošnjeg verskog života.

Tokom avgusta, oni su zajedno sa miletićkim jerejem Živojinom Bugarskim i suprugama, boravili u Bođanima. Ceo dan su proveli u društvu jeromonaha, oca Mitrofana, koji im je objašnjavao istoriju manastira. Tom prilikom, uručili su manastiru pomoć u iznosu od 3000 dinara, pri čemu im je uprava izjavila duboku blagodarnost.

Predsednik Svetozar Popović je na devetoj redovnoj sednici Privremenog poverenstva (18.10.1957) pokrenuo pitanje opravke velikog zvona koje „teško zvoni““.

Na kraju Letopisa za 1957. stoji da je godina bila veoma plodna. Svi usevi, pšenica, kudelja, repa, kukuruz su dobro rodili, što je bilo značajno za stanovništvo, koje se prevashodno bavilo zemljoradnjom.

Odlukom Eparhijskog upravnog odbora Pravoslavne eparhije bačke (br. 600, 23. XII 1957) potvrđeno je novo PP od 12 članova: Jovan Popović, Živojin Kozarević, Đurica Zarić, Lazar Popović, Momir Simić, Milutin Beljanski, Branislav Zarić, Marinko Beljanski, Milan Vidaković, Ivan Lazić, Žarko Katanić i Nedeljko Zarić, kao i osam zamenika: Lazar Radić, Vasa Veličković, Milan Tomašević, Vasilije Lazić, Petar Jezdimirović, Milenko Popović, Nikola Cvetičanin i Ilija Beljanski (Letopis parohije BB, 1955-1967, 58).

Svečana sednica novoizabranog Privremenog poverenstva (dalje: PP) na kojoj je razrešena stara uprava, uvedena nova, izvršeno konstituisanje i polaganje zakletve, održana je početkom januara 1958. godine. Za predsednika je izabran Jovan Popović, potpredsednika Ivan Lazić, sekretara protonamesnik i paroh Borivoje Č. Đorđević, blagajnika Milenko Popović, a tutori su postali Milan Lazić i Žarko Katanić.

Dana 14. 1. 1958. paroh je podneo Izveštaj o radu Uprave parohije i Crkvene opštine, tokom prethodne godine. Istaknut je zabrinjavajuće mali broj venčanih, ako se ima u vidu broj pravoslavnog stanovništva u mestu (Pogledati Pr. 1 na kraju rada).

Na Bogojavljenje jerej Đorđrvić je održao propoved, na temu, „Ovo je sin moj ljubazni koji je po mojoj volji, njega poslušajte“, a na Sabor Sv. Jovana Krstitelja „Pojanje kao uslov spasenja“.

Tokom decembra 1957. i januara 1958. godine, prikupljeno je ukupno 3230 dinara kao dobrovoljni prilog parohijana za srpske bogoslovije (Letopis parohije BB, 1955-1967, 60-61). 
Interesovanje za proslavu sv. Save, počelo je mesec dana pre ovog praznika. Deca su intenzivno dolazila kod paroha Đorđevića. Zajedno su spremali recitacije i duhovne pesme. Svetu liturgiju, sa početkom u 9 h, na Savindan 1958. godine, služio je mesni sveštenik. Pevao je hor učenika. Apostole su čitala školska deca: Marija Popović, Dara Vlaisavljević, Slobodanka Zarić, Dragan Todorović i Živa Zarić. „Prvi put posle oslobođenja“ kum slave bio je „kolonista“, Milivoje Vučković sa suprugom Milevim. Nakon rezanja slavskog kolača, usledio je dvosatni program školske dece. Izvedene su ukupno 54 recitacije i pesme.

Prva polovina februara bila je izuzetno topla, ali je uskoro nastupilo jako zahlađenje sa snegom i mrazevima, sve do Uskrsa. Za vreme Velikog posta, sveštenik je zapazio da se narod udaljava od svete tanje ispovesti i pričešća (Pogledati Pr. 2 na kraju rada). Takođe, uočio je da Brestovčani sve više rade na velike praznike, nedeljom, pa čak i na Uskrs. Sve to je navelo sveštenika da održi nekoliko propovedi o „Hrišćanskom pogledu na rad“, apelujući na vernike da te dane posvete bogu. Na Đurđevdan održao je propoved „Mučeništvo kao podvig velikog značaja“.

Arhijerejski namesnik, protojerej Dragutin Simić je 13. maja 1958. izvršio pregled rada parohije i Crkvene opštine. Za „Letopis“ je imao samo reči hvale: „Vrlo se lepo obrađuje i dopunjuje“ (Letopis parohije BB, 1955-1967, 66). Istog dana, obavljen je ispit dece koja su pohađala versku nastavu, kod paroha Đorđevića. Bilo je prisutno njih petnaest, u pratnji roditelja. Svi su sa upehom odgovorili na pitanja i rezultat je bio zadovoljavajući.

Drugog dana Duhova 1958. godine, katolički župnici iz Kucure, Krušćića i drugih mesta, u pratnji predstavnika katoličke crkvene opštine iz mesta, g. Sepa, posetili su pravoslavnu parohiju u Bačkom Brestovcu. Razgovor je protekao u prijateljskoj i ugodnoj atmosferi.

Početkom juna, paroh i Žarko Katanić obišli su Daljsku vodicu, koja predstavlja veliku svetinju. Dočekale su ih kaluđerice Eufemija i Teodora. Predali su im poklone u namirnicama i novcu, dar blagočestivih žena iz Bačkog Brestovca.

$\mathrm{Na}$ praznik Vidovdana, bilo je malo vernika u crkvi. Obavljen je parastos kosovskim junacima, a sveštenik je održao propoved, „Zemaljsko je maleno carstvo, a nebesko uvek i do veka".

Njegova svetost patrijarh SPC g. Vikentije, upokojio se 5. jula u Beogradu (Sava, episkop šumadijski, 1996, 77-79). To je uticalo na skromniju proslavu hramovne slave, a naročito „Čisto narodnog dela slave“. Praznično bdenije je slabo bilo posećeno. Liturgiju na dan svetih Apostola Petra i Pavla služili su: protonamesnik Đorđević, jerej Milan Nikolić, paroh somborski i jerej Živan Bugarski, paroh iz Srpskog Miletića. Bio je prisutan i hor iz Sivca. Večernje je počelo u 14 h i 30 min. Kum slave bio je predsenik Privremenog poverenstva Jova Popović. Jerej Bugarski je održao propoved, na temu, „Značaj hramovnih slava“.

Mesni paroh sa suprugom Olgom i bogoslovom Milanom Delićem, početkom avgusta, posetio je rimokatoličkog župnika g. Titla iz mesta. Razgovaralo se o problemima obe crkve. 
Materijalna situacija u parohiji, početkom 1959. bila je relativno zadovoljavajuća, jer su pokrivene redovne i vanredne potrebe crkvene opštine. Prvog dana Božića, prema starom običaju, mladići su se okupili u centru sela. Jahali su na konjima. Pevali su Božićne tropare, ulazile u domaćinske kuće, gde su služeni vinom i kolačima. Januarski praznici proslavljeni su sa zadovoljavajućim brojem vernika. Na Svetosavskoj svečanosti učestvovalo je preko pedeset dece. Izvedeno je ukupno 56 recitacija i duhovnih pesama.

Paroh je tokom zimskih meseci, na praznike koji su sledili, održao sledeće propovedi: Sv. arhiđakon Stefan - „Sv. Arh. Stefan kao pionir Hrišćanstva“; Nova godina - „Bogopoznanje je najveća sreća“; Bogojavljenje - „Bog među ljudima“; Sabor Sv. Jovana Krstitelja - „Pokajanje uslov spasenja“; Sv. Sava - „Uticaj sv. Save na srpski narod u prošlosti, sadašnjosti i budućnosti“; Sv. Tri jerarha - „Neimari hrišćanstva“; Sretenje Gospodnje - „Susret sa Gospodom“; Zimske Zadušnice - „Molitva za mrtve“; Poklade - „O značaju posta“; Prva nedelja posta - „Trijumf Pravoslavlja“.

Praznik rada (1. maj) 1959. pao je na crkveni praznik Veliki petak. Protonamesnik Đorđević je kratko konstatovao: „Žalosno je bilo pogledati kako naši pravoslavni Srbi toga dana nose sa pekare pečenje da se goste i vesele i ne misleći da je to dan kada je Bogočovek iskusio smrt za spas čovečanstva" (Letopis parohije BB, 1955-1967, 88). Brestovački paroh je 22. 5. 1959. učestvovao kao gost na hramovnoj slavi u Sivcu, u tek obnovljenom hramu.

Arhijerejski namesnik, Dragutin T. Simić 26. 5. 1959. je izvršio uobičajan pregled rada parohije i Crkvene opštine, te je sve uneo u Kontrolne knjige. Za Letopis je pribeležio: „Pohvalno, jer je svaki detalj primećen, lepo ubeležen i praćen" (Letopis parohije BB, 1955-1967, 91). Istog dana obavljen je ispit iz verske nastave, a deca su, po belešci u Letopisu, pokazala zavidno znanje, kao i poznavanje pesama duhovnog i religioznog karaktera. Dobrim delom, zasluga je za to pripadala parohu Đorđeviću. Iako je svega deset mališana izašlo na ispit, to ga nije zaustavilo u njegovom duhovnom radu.

Hramovna slava pala je te godine u nedelju. Žetva je bila završena, tako da su se stekli svi uslovi da veći broj ljudi učestvuje u svečanosti. Na „Strogo crkvenom delu slave“, pored brestovačkog paroha Đorđevića, učestvovali su protonamesnik Vojin Vukanović, paroh somborski, protojerej-stavrofor Ivan Popović, penzionisani paroh staparski, jerej Živan Bugarski, paroh miletićki i muški hor iz Sombora pod upravom g. Bogdana Laloševića. Protonamesnik iz Sombora je održao propoved na temu: „Hrišćanska ljubav sve pobeđuje“. „Narodno-crkveni deo slave" podrazumevao je večernje, vodoosvećenje i sečenje slavskog kolača. Usledio je „Čisto narodni deo slave“ u sali CO. Sve je bilo svečano, ali sa primetnom dozom tuge i žalosti. Naime, uoči slave izvršena je nacionalizacija dotične zgrade (Letopis parohije BB, 1955-1967, 99).

Na poziv sveštenika, u novembru, dvadeset parohijana se pretplatilo na časopis „Pravoslavni misionar“, koji je izlazio šest puta godišnje, i donosio tekstove verske i moralne sadržine. PP Srpske pravoslavne Crkvene opštine (dalje: SPCO) 
u Brestovcu održalo je tokom godine ukupno pet redovnih sednica, na kojima je doneto jedanaest odluka. Uglavnom, raspravljalo se o budžetu i izdavanju zemlje pod zakup.

Januar 1960. godine bio je veoma hladan. Malo vernika je bilo prisutno tokom ovog meseca, na velike praznike, u sv. hramu. Iako je narod slabo išao u crkvu, „redak je slučaj da na dan Božića uđete u neku srpsku kuću, a da u njoj nije obeležen taj najradosniji praznik vezan sa toliko lepih i tradicionalnih običaja“ pisao je ipak pun optimizma Borivoje Đorđević (Letopis parohije BB, 1955-1967, 106). Baš u to vreme, vršen je određeni pritisak od strane školskih radnika da nije slobodno ići u crkvu na versku nastavu. Upućen u socijalističko zakonodavstvo, paroh Đorđević je 14. 1. 1960. januara skrenuo pažnju vernicima na „Zakon o pravnom položaju verskih zajednica“, pozivajući roditelje da decu slobodno šalju na versku nastavu i proslavu Sv. Save. Na pomenuti crkveni praznik, paroh Đorđević je služio liturgiju i održao propoved: „Sv. Sava - duhovni vođa srpskog naroda“. Kumovi su bili Živa i Dušan Radić, sinovi Radovana Zarića. Na kraju je izveden svečani program, sa ukupno 40 duhovnih i religioznih recitacija.

Godina je bila izuzetno teška za članove parohije. O tome svedoče trzavice i optužbe od strane pojedinih članova Upravnog odbora SPCO na račun sveštenika, koje su bile neutemeljene i neistinite. Pale su mnoge teške reči a ,pred prostim i zlonamernim ljudima teško je bilo braniti se“, reči su sveštenika Đorđevića (Letopis parohije BB, 1955-1967, 113). Pomenuti događaji su se odigrali uoči hramovne slave, ali tok crkvenog života nije zaustavljen. Baš suprotno. U duhu hrišćanske misli razmišljao je paroh na stranicima svog hronografa: „Iako je doba materijalističko, iako se danas mnogo više ugađa telu nego duši, ipak s vremena na vreme zablista ono što je duhovno, trajno i neprolazno“ (Letopis parohije BB, 1955-1967, 114).

Na Petrovdan liturgiju su služili mesni paroh, jerej Milan Nikolić, paroh somborski, jerej Živan Bugarski, paroh miletićki i jerej Ilija Danilovac, paroh deronjski. Bili su prisutni pojci iz Stapara i Deronja. Tom prilikom, jerej Nikolić održao je rečitu propoved, na temu, „Savremena nauka i religija“. Večernje je služio jerej Bugarski, a obred vodoosvećenja i sečenja slavskog kolača paroh Danilovac, koji je održao propoved „Značaj hramovnih slava i vere za naš narod“.

Upravni odbor SPCO održao je pet redovnih i tri vanredne sednice, na kojima je doneto 26 odluka, te godine.

Na Božić 1961. sv. liturgiju služili su bivši bačko-brestovački paroh Konstantin Jorgović (koji je u selu boravio kao rado viđen gost) i paroh Đorđević. Za praznike su održane dve poučne propovedi: „Poklon Vitlejemskom Mladencu“ i „Oprosti im Bože jer ne znaju šta rade“. Sveštenik je na Novu godinu pozvao vernike da se više okrenu duhovnom životu i materijalno pomažu svoju versku zajednicu. Priredba za Sv. Savu je po rečima prisutnih bila lepa i svečana. Naime, jedna je starija žena, na izlasku iz crkve navodno rekla: „Da mi je da ova svečanost duže traje. Sve mi je to tako kratko bilo i kada je sveštenik objavio da je kraj, žao mi je bilo što nema još toliko dece i što sva deca ne učestvuju u ovoj divnoj i 
nezaboravnoj svečanosti““ (Letopis parohije BB, 1955-1967, 122). Treba naglasiti da prosvetne vlasti te godine nisu pravile smetnje, niti zastrašivale decu.

Paroh je na sv. Tri jerarha održao propoved „Vera treba da je živa“, o Zadušnicama „Pomen za umrle“, za Blagovesti „Blaga vest i strašna vest“, a na Cveti „Doček Spasitelja“.

Sreska komisija za nacionalizaciju uručila je rešenje (br. 09/b. 1344/718 od 18. 12. 1959) 5. maja 1961. o delimičnoj nacionalizaciji kuće zvana „Škola“. CO je na taj način mesečno gubila 30000 dinara, koliko je dobijala na ime kirije. Sala je ostala u svojini Crkvene opštine. Na Vidovdan 1961. godine naroda je bilo veoma malo u crkvi. Da li je to bio znak da vernici zaboravljaju svoje velike svetinje i tradicije koje su ga krasile kroz vekove? - pitao se paroh-letopisac u svom delu.

Bez obzira na mnogobrojne probleme, koji su bili povezani sa tim teškim godinama za duhovni život, hramovna slava je proslavljena svečano i dostojanstveno. Liturgiju su služili protojerej Konstantin Jorgović i protonamesnik Đorđević. Na večernju je paroh govorio o „Univerzalnom značaju religije“. Svojim pojanjem, Žarko Aperlić, predsednik CO iz Stapara i Miša Parabuđski iz istoimenog mesta, su uveličali ovaj događaj. Upravni odbor SPCO u Bačkom Brestovcu održao je 1961. godine 6 redovnih i 3 vanredne sednice, na kojima je doneto 28 odluka.

$\mathrm{Na}$ Svetosavskoj proslavi 1962. godine, predškolska, školska i vanškolska deca su učestvovala u velikom broju. Kumovi slave bili su Stojan i Stojanka Zarić, a za narednu godinu se prijavio Dragomir Todorović.

Predsednik Upravnog odbora (dalje: UO) SPCO je na petoj redovnoj sednici predložio da o sopstvenom trošku opravi prag na severnim ulaznim vratima crkve, što je jednoglasno prihvaćeno (Zapisnik UO SPCO 19.2.1956-3.1.1972, Peta redovna sednica 12. 3. 1962). Krajem juna, krst koji se nalazio pred bivšom veroispovednom školom je premešten u portu crkve (na jugo-istočnu stranu). Posao su obavili kamenoresci iz Stapara (Zapisnik UO SPCO 19.2.1956-3.1.1972, Jedanaesta redovna sednica 3. 6. 1962). Liturgiju na dan hramovne slave 1962. godine služili su arhijerejski namesnik somborski protojerej Dragutin Simić i mesni paroh. Sve je dodatno bilo ulepšano prisustvom Bogomoljačkog hora iz Sombora, pod upravom Đure Simića, a za pevnicom su se nalazili pojci iz Deronja i Stapara. Kumovi slave bili su Živko Balatinac, vozovođa iz Sombora, i njegova supruga Kata, rodom iz Bačkog Brestovca. Oni su načinili prvi veći dar crkvi u poslednjih desetak godina (1952-1962).

Prema raspisu episkopa bačkog g. Nikanora (5. 2. 1961) „dosadašnji antimisi biće zamenjeni novim u Eparhiji“" (Letopis parohije BB, 1955-1967, 147). Oni su bili osvećeni u toku Uskršnjeg posta. U njima su bile ,ušićene mošti sv. Velikomučenika Georgija“, koje je episkop Nikanor doneo iz Jerusalima. Antimis za crkvu u Bačkom Brestovcu jerej Đorđević je primio 14. 7.1962. godine, u Eparhijskom dvoru u Novom Sadu, lično od g. Nikanora. Prva liturgija na novom sv. Antimisu održana je na praznik „Polaganje rize Presvete Bogorodice“. Dva starija antimisa iz Brestovačkog hrama: jedan iz 1914. godine od episkopa Mitrofana Ševića i 
drugi iz 1937. od episkopa Irineja Ćirića, predati su za eparhijsku riznicu (Sava, episkop šumadijski, 1996, 321-322).

Januar 1963. bio je izuzetno hladan i snegovit, što se odrazilo i na broj prisutnih vernika u crkvi tokom velikih pravoslavnih praznika. Svetosavska proslava je organizovana svečano. U potpunosti je opravdala verski i nacionalni karakter. Na sednici UO SPCO, koja je održana 1. januara doneta je odluka da se za decu (učesnike programa) spreme pokloni u vidu paketića. Takođe, predviđena je podela knjižica religioznog i moralnog karaktera, izdanja Svetog arhijerejskog sinoda (Zapisnik UO SPCO 19.2.1956-3.1.1972, Prva redovna sednica 1.1./19.12.). Naročito se želelo tim činom istaći da je proslava ,slobodna i u duhu postojećeih zakonskih pravila" (Letopis parohije BB, 1955-1967, 156). Deo dece obučen u stihare, sa čiracima i ripidama, stajao je pred oltarom. Apostole su čitali Danica Jezdimirović, Zoran Despotov, Milica Stanić i Mile Beljanski. Kumovi slave, te godine, bili su Dragomir i Jelica Todorović, deca Stevana i Gospojinke (rođ. Stanić) Todorović. Pomenuta deca su godinama redovno uzimala učešća u svetosavskim proslavama, što je paroh Đorđević posebno konstatovao. Za narednu godinu, kumstvo je prihvatila Vladimirka Beljanski, učenica trećeg razreda.

Na Đurđevdan, 1963. godine bilo je dosta sveta u crkvi, naročito žena - naseljenika. Tom prilikom, paroh Đorđević je održao propoved „Tradicionalno proslavljanje Đurđev-dana u našem narodu“.

Arhimandrit Stevan Ilkić, upravitelj Zadužbine Stevan Konjović u Somboru, istaknuti prosvetni i kulturni radnik, čovek cenjen i van SPC, upokojio se 9. maja 1963. godine. Njegovoj sahrani prisustvovali su episkop bački g. Nikanor, protojerej Miloš Lučić, prota Milan Smiljanić, prota Blagoje Berdić, kao i šesnaest sveštenika, uključujući i paroha bačko-brestovačkog, protonamesnika Đorđevića.

UO SPCO u Bačkom Brestovcu sklopio je 16. juna ugovor sa električarima (Rade Maričić i Mile Kosovac). Trebalo je izvršiti prepravku električne mreže u crkvi i parohijskom domu. Reč je o uvođenju trofazne struje, prema propisima JUS-a.

Hramovna slava (Petrovdan) proslavljena je 1963. skromno i lepo. Obeležen je mali jubilej: „Dve stotine dvadeset godina od kako je hram podignut - podignut je 1743, a osvećen 1744. godine“ (Letopis parohije BB, 1955-1967, 164). Bila je to 220-a hramovna slava. Lepo i nadahnuto u Letopisu povodom ovog događaja paroh Đorđević je napisao: „Ko, u ovom selu, ili ma u kom mestu, može da se pohvali ovakvom proslavom? Sve prolazi, sve je kratkog veka i sve nastaje i umire, samo crkva Hristova neprestano i večno vrši svoju uzvišenu, spasonosnu i Božansku misiju“ (Letopis parohije BB, 1955-1967, 164). U narečenom periodu, bilo je raznih vremena, događaja lepših i manje lepih, raznih ljudi, čestitih, poštenih i dobrih, ali i onih drugih, međutim sve je to prošlo, ,jedino je sv. Hram ostao kao verni čuvar pravoslavnih Srba u mestu“ (Letopis parohije BB, 1955-1967, 165).

Bez obzira na sve smetnje, uzimajući u obzir vreme i prilike, u Bačkom Brestovcu je slava proslavljena na zadovoljavajući način. Po prvi put, u Letopisu nailazi se na podatak o prodavanju igračaka i „raznih stvarčica“ ispred sv. hrama, na dan slave. Te godine, bdenije uoči praznika služio je gost Uprave parohije i 
Crkvene opštine, jerej Milan Delić, paroh čuruški (1961-1975), rodom iz Bačkog Brestovca (Todić \& Todić, 2012, 134). Sv. liturgiju, na dan slave, služili su jerej Ilija Danilovac, paroh staparski i jerej Milan Delić. Vernika nije bilo puno, ali je za promenu bilo više kolonista u odnosu na starosedeoce. Tom prigodom, osvećen je krst, koji je prenet u portu (nalazio se ispred bivše Veroispovedne škole). Večernje, vodoosvećenje i sečenje slavskog kolača izvršili su protonamesnik Đorđević i jerej Danilovac. Kum slave bio je Boža Vlaški iz Kule sa suprugom Ružom (rođ. Sekulić), poreklom iz sela. Kumstvo za narednu godinu primili su se kolonisti, siromašni i čestiti ljudi, Milivoj Vučković i njegova žena Mileva. Nakon toga, usledio je narodni deo slave.

SPC, kao i brestovačka parohija, sa velikom tugom je primila vest o strašnom zemljotresu koji je jula meseca 1963. zadesio Skoplje. Njegova svetost patrijarh srpski gospodin German je 1. VIII 1963. posetio razoreni grad. U nevolji, ljudi se okupljaju, pomažu i saosećaju. Siromašna Uprava parohije i CO, na čelu sa parohom Đorđevićem, učinila je napor da pruži pomoć postradalom gradu. Vernici u Bačkom Brestovcu, iako skromnih materijalnih primanja, prikupili su 12600 dinara kao pomoć napaćenim ljudima. Upravni odbor CO 1963. održao je četiri redovne i dve vanredne sednice, na kojima je doneto 18 odluka, koje su se odnosile na verski i duhovni život.

Svetosavska proslava 1964. godine predstavljala je mali jubilej. Punu deceniju, paroh Đorđević je vredno i neumorno radio na njenoj organizaciji. Duh srpskog svetosavlja se kod naroda, dece i omladine održao, bez obzira na mnogobrojne probleme. Te godine je oko pedeset dece učestvovalo u programu, a bio je prisutan i ogroman broj naroda. Još od Božića, a naročito tokom školskog raspusta, brestovačka deca su redovno, svaki dan, dolazila u crkvu. Provodili su po tri sata u pevanju i recitovanju duhovnih pesama, a sveštenik je održavao i versku nastavu. Vrlo brzo su savladali osnovne pojmove o pravoslavnoj veri. Bitno je istaći da su sve odabrane recitacije predstavljale određene metodske jedinice, i stoga su bile verske i duhovne sadržine. Od Vladimirke Beljanski i Mirjane Ilić te godine, kumstvo su preuzele Zorica i Danica Jezdimirović (Letopis parohije BB, 19551967, 175-176).

Na prostoru cele Vojvodine i južne Panonije, 13. aprila 1964. godine, osetio se zemljotres, koji je naviše pogodio Slavonski Brod. Od njegove siline na parohijskom domu je pao odžak.

Pete nedelje posta (19. 4. 1964) osnovana je „Hrišćanska zajednica i Dobrotvorno starateljstvo" u brestovačkoj parohiji. To je bilo u direktnoj vezi sa naređenjem Episkopa Bačkog g. Nikanora (E. Br. 32, od 8.2.1964). Veoma brzo, upisalo se dvadeset članica. Svake nedelje održavani su sastanci. Već za Uskrs, članice Hrišćanske zajednice su dobrovoljno spremile crkvu, opremile i ukrasile Hristov grob.

Na Veliku Subotu, 1964. godine, episkop bački g. Nikanor u pratnji sekretara, protonamesnika, Veselina Petrovića, posetio je brestovački hram. Celivao je plaštanicu i interesovao se za crkveni život u parohiji, naročito tokom Cvetne nedelje. Poseta je bila krtka i iznenadna. Put ih je zatim odveo za Srpski Miletić. O Uskrsu, 
Marija Đurkić je priložila pokrivač od bordo somota za crkvu, čija vrednost je iznosila 9200 dinara.

Kako bi hramovna slava bila što svečanije proslavljena, UO SPCO je doneo odluku da pozove na ovaj događaj episkopa bačkog g. Nikanora, koji bi svojim prisustvom i arhipastirskim rečima uveličao događaj (Zapisnik UO SPCO 19.2.1956-3.1.1972, Druga redovna sednica). Već na sledećoj sednici (održana 28. 6. 1964) rešeno je da svi članovi Upravnog odbora dobiju određena zaduženja na sam dan slave.

Članice Hrišćanske zajednice su uzele vidno učešće u pripremama za ovu svečanost. Najpre je dogovoreno da se kupi prekrivač za sveti presto. Prikupljena je suma u iznosu od 64150 dinara (Letopis parohije BB, 1955-1967, 181-182). Preostali novac je utrošen za krečenje crkve, farbanje ograde na porti i druge potrebe. Treba napomenuti da su žene dobrovoljno uzele učešća u krečenju crkve, i dale određene priloge u naturi. U to vreme, tri žene su učinile naročite priloge svojoj crkvi, povodom lepog jubileja i dolaska Episkopa u posetu. Kata Sekunčić je priložila crnu odeždu, Drenka Radić ručni krst, a Mara Okrajinov lepu svetlu odeždu.

Poseta episkopa g. Nikanora 1964. Bačkom Brestovcu predstavlja događaj od prvorazrednog značaja za istoriju ovdašnje crkve. Po svedočanstvu Borivoja Đorđevića, svi su se bržljivo pripremali za ovaj događaj. Crkveni odbor održao je više redovnih i vanrednih zasedanja na kojima su rešavana pitanja u vezi sa hramovnom slavom. Dan uoči hramovne slave, u 14 h protojerej-stavrofor Ivan Popović, penzionisani paroh iz Stapara i bačko-brestovački paroh Đorđević izvršili su osvećenje svih darova koje su tokom leta priložili parohijani. Uskoro je stigao i protonamesnik, paroh somborski, Uroš Jovankin.

Sveštenici, đaci, devojčice sa cvećem, članovi Upravnog odbora i narod sa nestrpljenjem su čekali momenat dolaska episkopa Bačkog. Oko 17 h pojavio se g. Nikanor, u pratnji sekretara protonamesnika Veselina Petrovića i arhijerejskog namesnika protojereja Dragutina Simića, ispred Crkve svetih apostola. Odmah su se oglasila i zvona. Prota Ivan Popović mu je predao krst, a učenica Milosava Popović ga je pozdravila recitacijom „Dobro nam došao Vladika sveti“ i uručila mu buket sa svežim karanfilima. Odabranim rečima, obratio mu se predsednik Upravnog odbora Vujadin Lazić. Devojke, Jelica Todorović i Nada Đidić, su mu predale cveće. Po starom i lepom običaju, Gospojinka Todorović i Dana Despotov su uvele Vladiku „po platnu“ u sv. hram, koji je potom stao u svoj Arhijerejski sto. Praznično bdenije je služio Episkop sa sveštenicima, čije pojanje je ostavilo snažan utisak na prisutni narod.

Na sam dan slave, 1964. godine, sv. liturgiju služili su Vladika, protojereji Ivan Popović i Dragutin Simić, protonamesnici Veselin Petrović i Uroš Jovankin, kao i paroh Đorđević. Sve je upotpunio muški hor Velike crkve iz Sombora, pod upravom g. Bogdana Laloševića (Letopis parohije BB, 1955-1967, 185). Crkva je bila puna sveta. Osećala se nesvakidašnja duhovna radost u vazduhu jer je ovo bio jedinstven događaj u istoriji brestovačkog hrama. Vladika je održao Arhipastirku propoved, sa akcentom na čuvanju i negovanju vere kod Srba. 
Večernje sa početkom u 15 h tog dana služio je protonamesnik Veselin Petrović, a odgovarao je muški hor iz Sombora. Gospodin Nikanor sa kumom (Mileva Vučković sa sinom Stanišom) i mesnim parohom je izvršio sečenje kolača. Episkop je pohvalio revnost kumova i domaćina. Oko $16 \mathrm{~h}$ deleći arhijerejski blagoslov svim prisutnim vernicima, episkop je napustio Bački Brestovac.

Božićni praznici 1965. proslavljeni su u brestovačkom hramu svečano. Usledile su pripreme za proslavu Sv. Save. Uprani odbor je 4. 1. 1965. posebnu tačku dnevnog reda posvetio ovom događaju, kako bi svetosavska proslava prošla u što svečanijem raspoloženju (Zapisnik UO SPCO 19.2.1956-3.1.1972, Druga redovna sednica, 4. januar). Tokom januarskih praznika, apelovalo se na roditelje, da svoju decu puste da učestvuju u svetosavskom programu, jer kroz recitacije religiozne sadržine i duhovne pesme, stiču osnove pravoslavne vere. Tokom školskog raspusta, sa oko 40 prijavljene dece, sveštenik je svaki dan držao po dva sata verske nastave i vršio pripreme za proslavu.

$\mathrm{Na}$ sam dan praznika, deca sa krstom i ripidama su stajala kraj oltara. Kumovi slave su bile Danica i Zorica Jezdimirović, ćerke Jovana i Sofije Jezdimirović. Nakon vodoosvećenja i sečenja kolača, paroh je svima čestitao slavu, a malim kumicama je poželio da im ,slava uvek služi kao putokaz na njihovom daljem životnom putu i da ih neprestano prati blagoslov sv. Save“" (Letopis parohije BB, 1955-1967, 191). Četvrt kolača, kao zalogu kumstva za narednu godinu, primili su Đorđe i Boško, sinovi Vujadina i Nade Lazić.

Tokom maja 1965, po rečima Letopisa, patrijarh Srpski g. German, sa visokim predstavnicima SPC, osvetio je Spomen crkvu sa Kosturnicom u Lazarevcu. Ovom činu je prisustvovao i paroh Borivoje Č. Đorđević, zaslužan za njeno podizanje (Letopis parohije BB, 1955-1967, 193).

Početkom juna 1965. Dunav se izlio u neposrednoj blizini mesta. Čak pedeset dana trajala je ljudska borba sa vodenom stihijom. Brestovčani su aktivno učestvovali u ovim akcijama (Zapisnik UO SPCO 19.2.1956-3.1.1972, Treća redovna sednica, 4. 7. 1965). Paroh je sa vernicama prikupljao priloge. Sve je upućeno u poplavljene krajeve. Nesrećni događaji su uticali na odluku Upravnog odbora da se hramovna slava proslavi što skromnije. Namenska sredstva za tu prigodu su preusmerena kao pomoć u poplavljene krajeve. Petrovdan 1965. proslavljen je skromno i umereno, bez trećeg sastavnog dela „Čisto narodnog dela slave“. Liturgiju su služili protonamesnik Vojin Vukanić, paroh somborski i mesni paroh. Gospodin Vukanić je održao propoved, na temu, ,Mnogi naši sinovi i kćeri postideli su se od svoje crkve“.

Na osnovu odluke pravoslavnog episkopa Bačkog (br. 246, od 5. XI 1965.), protonamesnik Borivoje Č. Đorđević je premešten, po molbi, na parohiju u Čurug, arhijerejsko namesništvo žabaljsko. Tamo je bio sveštenik u periodu od 1965. do 1973. godine (Todić \& Todić, 2012, 134). Ovaj značajan čovek ostavio je dubok trag u životu stanovnika Bačkog brestovca i ujedno je bio hroničar ovog mesta. Novi bačko-brestovački paroh postao je jerej Milenko Blagojević. 


\section{Prilog: 1}

Tabelarni prikaz: Obredno kršteni, venčani i sahranjeni (1955-1964) u Bačkom Brestovcu $^{3}$

\begin{tabular}{|c|c|c|c|}
\hline Godina & Kršteni & Venčani & Sahranjeni \\
\hline 1955. & 36 & 3 & 14 \\
\hline 1956. & 29 & 6 & 13 \\
\hline 1957. & 11 & - & 9 \\
\hline 1958. & 28 & 2 & 16 \\
\hline 1959. & 22 & 2 & 24 \\
\hline 1960. & 24 & 2 & 22 \\
\hline 1961. & 29 & 3 & 11 \\
\hline 1962 & 25 & - & 11 \\
\hline 1963. & 19 & - & 12 \\
\hline 1964. & 18 & 4 & 17 \\
\hline
\end{tabular}

\section{Prilog: 2}

Tabelarni prikaz: Ispoveđeni i pričešćeni (1958-1964) u Bačkom Brestovcu

\begin{tabular}{|c|c|}
\hline Godina & Broj \\
\hline 1958. & 492 \\
\hline 1959. & 444 \\
\hline 1960. & 443 \\
\hline 1961. & 372 \\
\hline 1962. & 382 \\
\hline 1963. & 382 \\
\hline 1964. & 348 \\
\hline
\end{tabular}

Snežana Božanić

\section{HISTORY OF BAČKI BRESTOVAC IN THE DISCOURSE OF CHURCH ACTIVITIES OF BORIVOJ Č. DJORDJEVIĆ (1954-1965)}

\section{SUMMARY}

Borivoje Č. Đorđević is highly credited for raising the Memorial church with crypt in Lazarevac, where are buried the remains of participants in the Battle of Kolubara. At the end of 1954. he was appointed as a priest in the Orthodox church in Bački Brestovac. Half a year later, the significant works were carried on the church. The bishop of Bačka, Nikanor, was visiting the parish several times, of which there is a significant written testimony.

3 Tabela je nastala na osnovu: Matrikule krštenih, venčanih i umrlih pravoslavnog hrama sv. Apostola Petra i Pavla u Bačkom Brestovcu 1955-1964. Arhiv pravoslavnog brestovačkog hrama sv. Apostola Petra i Pavla. Bački Brestovac. 
This great man has left a deep and indelible mark on the spiritual and historical stage of Bački Brestovac.

Key words: Borivoje Č. Đorđević, Saints Peter and Paul in Bački Brestovac, Church history

\section{IZVORI I LITERATURA}

Andraši, Olga (2001). Bački Brestovac od sredine XVI do potkraj XVIII veka. Zbornik Matice srpske za istoriju. 63-64: 19-56.

Andraši, Olga (1998). Prvih pola stoleća bačkobrestovačke pravoslavne crkve Sv. Apostola Petra i Pavla. Seoske i slašarske crkve u Vojvodini. XIV: 402-404.

Borovszky, Samu (1909). Bács-bodrog vármegye I. Budapest: A Magyar Tudományos Akadémia épületében.

Gaćeša, Nikola (1968). Agrarna reforma i kolonizacija u Bačkoj 1918-1941. Novi Sad: Matica srpska.

Episkop Nikolaj (2001). Ohridski Prolog. Linc: SPCO Linc.

Zapisnik sednica Crkveno-opštinske uprave od 21. januara 1940. godine do 25. decembra 1955. godine. Arhiv pravoslavnog brestovačkog hrama sv. Apostola Petra i Pavla. Bački Brestovac.

Zapisnik Upravnog odbora Srpske pravoslavne crkvene opštine od 19. februara 1956. do 3. januara 1972. godine. Arhiv pravoslavnog brestovačkog hrama sv. Apostola Petra i Pavla. Bački Brestovac.

Krnjajić Miomir, Ižak Bela (1987). Isečci iz Letopisa. Odžaci: Informativni centar Odžaci

Lazić, Milisav (1998). Ikone bačkobrestovačke pravoslavne crkve Sv. Apostola Petra i Pavla. Seoske i slašarske crkve u Vojvodini. XIV: 405-411.

Letopis Crkvene Opštine i parohije Bački Brestovac od 1955. do 1967. godine. Arhiv pravoslavnog brestovačkog hrama sv. Apostola Petra i Pavla. Bački Brestovac.

Matrikule krštenih, venčanih i umrlih pravoslavnog hrama sv. Apostola Petra i Pavla u Bačkom Brestovcu 1955-1964. Arhiv pravoslavnog brestovačkog hrama sv. Apostola Petra i Pavla. Bački Brestovac.

Popović, J. Dušan (1925). Vojvodina, Prilozi proučavanju naše zemlje i našeg naroda, Opšti deo I, Bačka, Prilozi proučavanju etničkih odnosa od sredine XVI veka do 1921 g. Beograd: SKA.

Sava, episkop šumadijski (1996). Srpski jerarsi od devetog do dvadesetog veka. Beograd, Pogdorica, \&Kragujevac: EVRO, UNIREKS, \&KALENIĆ.

Srećković, Panta (1884). Autobiografija Atanasija Nikolića. GSUD. 59: 115-118.

Todić Milanka, Todić Branislav (2012). Crkva Vaznesenja Gospodnjeg u Čurugu. Čurug: Srpska Pravoslavna Crkvena Opština Čurug. 